\title{
The Effect of Lack of a Carbon Source on Nitrate-reductase Activity in Aspergillus nidulans
}

\author{
By M. J. HYNES \\ Department of Genetics, La Trobe University, Bundoora, Victoria 3083, Australia
}

(Received I3 April 1973; revised 28 May 1973)

Control of nitrate-reductase levels has been extensively studied in Aspergillus nidulans (Pateman \& Cove, I 967; Cove \& Pateman, 1969). During studies on the interaction between regulation of carbon metabolism and regulation of nitrogen metabolism (Hynes, 1972) preliminary evidence has been obtained indicating that a gene involved in the interaction affects growth of $A$. nidulans on nitrate and nitrite (M. J. Hynes, unpublished). A study of the effects of carbon starvation on nitrate-reductase levels has therefore been carried out.

Mycelium of the wild-type strain, biA-I, was grown under inducing conditions and then transferred to various media and incubated further. Mycelial samples of 20 to $30 \mathrm{ml}$ were harvested at intervals and assayed for nitrate-reductase activity by the method of Cove (I966) with the modified control of Lewis \& Fincham (1970).

As shown in Fig. I $(a, b)$, nitrate-reductase activity rapidly disappeared in medium in which further synthesis of the enzyme was not possible or in medium lacking a carbon source. Absence of inducer and repression by ammonium caused rapid loss of activity as has been shown previously for Aspergillus nidulans (Cove, 1966), Neurospora crassa (Subramanian \& Sorger, 1972) and Ustilago maydis (Lewis \& Fincham, 1970). In the latter organisms protein-synthesis inhibitors prevent this inactivation. The results presented here indicated that cycloheximide, at $10 \mu \mathrm{g} / \mathrm{ml}$, only slightly reduced the rate of enzyme loss and, in fact, cycloheximide itself caused loss of nitrate-reductase activity. A lower concentration of cycloheximide (I $\mu \mathrm{g} / \mathrm{ml}$ ) had a similar effect. Methylammonium chloride, which does not serve as a nitrogen source for the strain mau A-2 (Arst \& Cove, 1969) caused rapid loss of activity in this strain (results not shown).

An even greater rate of enzyme disappearance was found when mycelium was starved for carbon. The rates of inactivation were similar when brought about by carbon starvation in the presence of inducer or inducer plus ammonium, or in the absence of inducer. This suggests that there is only one mechanism of inactivation operating under the various conditions.

The data in Fig. I $(c)$ show that inactivation of nitrate reductase was also found in the mutant nir $\mathrm{A}^{\mathrm{e}}$ - $\mathrm{I}$, which produces nitrate reductase in the absence of inducer (Pateman \& Cove, 1967). This strain was grown in glucose-minimal medium with $5 \mathrm{~mm}$-urea as sole nitrogen source before transfer to various media. Both ammonium repression and carbon starvation resulted in loss of activity. Transfer to medium lacking a nitrogen source resulted in an increase in activity, presumably owing to relief of repression by ammonium produced during growth on urea. This indicates that starvation for nitrogen in itself does not cause inactivation.

Rapid loss of enzyme activity with starvation for a carbon source is not a unique property of nitrate reductase. Unpublished experiments have shown that NADP-glutamate dehydrogenase and glucose-6-phosphate dehydrogenase activities rapidly decrease in the absence of 

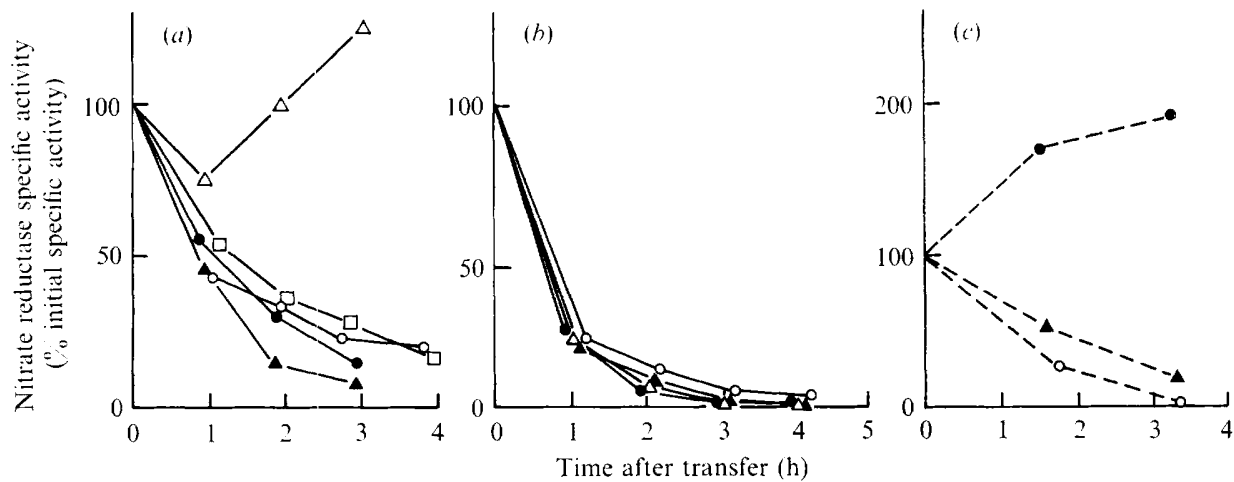

Fig. I. Disappearance of nitrate reductase activity under various growth conditions. $(a, b)$ Wild-type pre-induced with $10 \mathrm{~mm}-\mathrm{NaNO}_{3} ;(a)$ glucose-minimal medium; $(b)$ minimal medium lacking a carbon source; $(c)$ nir $\mathrm{A}^{\mathrm{c}}-\mathrm{I}$ pre-grown on glucose-5 mM-urea medium. $-\mathrm{O}$, no nitrogen source;

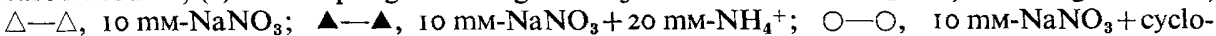

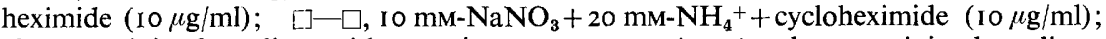
glucose-minimal mediurn with no nitrogen source; $\boldsymbol{\Delta}_{--\boldsymbol{\Lambda}}$, glucose-minimal medium + Io $\mathrm{mm}$ $\mathrm{NaNO}_{3}+20$ mM- $\mathrm{NH}_{4}{ }^{+} ; \bigcirc--\mathrm{O}$, minimal medium lacking a carbon source $+10 \mathrm{mM}-\mathrm{NaNO}_{3}$.

a carbon source, but for these two enzymes cycloheximide prevents the inactivation. It is not known if this loss of enzyme activity is due to protease action on the enzymes. An attempt to demonstrate in vitro inactivation of nitrate reductase and glutamate dehydrogenase by mixing crude mycelial extracts and incubating was not successful. However, this experiment did show that it was unlikely that accumulation of an inhibitor of the enzymes during carbon starvation could account for the results.

It has been shown previously that Aspergillus nidulans produces increased amounts of an acetamidase enzyme upon carbon starvation even in the absence of inducer (Hynes, 1970, 1972). Pre-induced $\beta$-galactosidase activity is not rapidly lost from carbon-starved mycelium, nor does the activity of this enzyme increase in medium lacking a carbon source in the absence of an inducer (M. J. Hynes, unpublished). Therefore it seems that various enzymes show different responses to carbon starvation and different absolute requirements for the presence of inducer. In the case of nitrate reductase there is an absolute requirement for inducer and for the presence of a carbon source. If inactivation of enzymes upon carbon starvation involves protease digestion of the enzyme protein, then this would provide an additional source of carbon and nitrogen for the organism.

Cove $(1972 a, b)$ has shown that nitrate and chlorate inhibit the utilization of various nitrogen sources and that the nitrate-reductase enzyme protein is required for this inhibition. It has been found that Io mM-sodium nitrate inhibits the utilization of acetamide as a nitrogen source in the strain niiA-4 which is unable to utilize nitrate owing to lack of nitritereductase activity (Pateman \& Cove, I967). Potassium chlorate (I50 mM) inhibits utilization of acetamide as sole nitrogen source by both wild-type and niiA-4 strains. Various mutants with altered nitrate reductase are resistant to these inhibitions. In contrast to these effects on the utilization of acetamide as a nitrogen source, nitrate and chlorate do not inhibit the utilization of acetamide as sole carbon and nitrogen source. The effect of the absence of a carbon source on nitrate-reductase activity reported here may be of importance in explaining these observations and further studies are required. 


\section{REFERENCES}

ARst, H. N. \& Cove, D. J. (I969). Methylammonium resistance in Aspergillus nidulans. Journal of Bacterio$\log 98$, $1284-\mathrm{I} 293$.

Cove, D. J. (1966). The induction and repression of nitrate reductase in the fungus Aspergillus nidulans. Biochimica et biophysica acta $\mathbf{1} 3,5 \mathrm{I}-56$.

Cove, D. J. (1972a). Chlorate toxicity in the fungus Aspergillus nidulans. Biochemical Journal 127, 19 P.

Cove, D. J. (1972 b). The control of nitrogen metabolism in Aspergillus nidulans. Heredity 29, I 19.

Cove, D. J. \& Pateman, J. A. (1969). Autoregulation of the synthesis of nitrate reductase in Aspergillus nidulans. Journal of Bacteriology 97, I 374-1 378.

HyNes, M. J. (1970). Induction and repression of amidase enzymes in Aspergillus nidulans. Journal of Bacteriology 103, 482-487.

HyNES, M. J. (I972). Mutants with altered glucose repression of amidase enzymes in Aspergillus nidulans. Journal of Bacteriology III, 71 7-722.

Lewis, C. M. \& Fincham, J. R. S. (1970). Regulation of nitrate reductase in the basidiomycete Ustilago maydis. Journal of Bacteriology ro3, 55-6I.

Pateman, J. A. \& Cove, D. J. (1967). Regulation of nitrate reduction in Aspergillus nidulans. Nature, London 215, $1234-1237$.

Subramanian, K. N. \& Sorger, G. J. (1972). Regulation of nitrate reductase in Neurospora crassa: stability in vivo. Journal of Bacteriology 110, 538-546. 